\title{
Abstracts of Papers Presented at the Annual Meeting
}

\section{Testing for Employer Monopsony in Turn-of-the- Century Coal Mining}

Isolated company towns are often cited as likely examples of labor monopsony. This study tests for monopsony power by estimating inverse labor supply elasticities using a county-level panel data set on nonunion West Virginia coal mining from 1897 to 1932. The model specification incorporates dynamics in such a way that an estimate of the gap between marginal revenue product and the wage can easily be computed as a weighted average of short- and long-run inverse elasticities. Modest estimated short-run inverse elasticities and very small long-run inverse elasticities imply that coal operators enjoyed little, if any, monopsony power over their workers.

William M. Boal, Ohio State University

\section{A Prelude to the Welfare State: Compulsory State Insurance and Workers' Compensation in Minnesota, Ohio, and Washington, 1911-1919}

Dissatisfaction with the high transaction costs of compensating workers for their injuries led seven states in the 1910 s to enact legislation requiring that employers insure their workers' compensation risks through exclusive state insurance funds. This paper traces the political-economic history of the success of compulsory state insurance in three states in the 1910s-Minnesota, Ohio, and Washington. State insurance gained broad support in these states because a coalition of progressive legislators took control of their respective legislatures, bringing with them the idea that government had the unique ability to correct market imperfections. The political environment in which state insurance thrived in the 1910s provides important insights into the growth of government in the 1930s and 1960s. The major social insurance programs of the New Deal and the Great Society were widely supported at the time because the private market was seen as unable to solve a particular problem, such as unemployment compensation or poverty in old age. This paper argues that the government's dramatic expansion after the 1932 federal election was not unprecedented; in fact, the ideological roots of New Deal activism were planted during the debates over compulsory state insurance and workers' compensation in the 1910s.

Price V. Fishback and Shawn Everett Kantor, University of Arizona and National Bureau of Economic Research

\section{The Company Town, the Union, and the Mine Wars: The Role of Institutions and Conflict in West Virginia's Early Mine-Labor Market}

During the early twentieth century, the American mining industry was plagued by massive labor conflicts. At the time, these conflicts, known as the "mine wars," were viewed as distributional conflicts caused by the inefficient organization of the mine-labor 
market. Union supporters blamed the company town and called for its abolition. Mining firms blamed the union, asserted it was trying to achieve a labor monopoly, and called for its elimination. This paper assesses both of these claims empirically. A model of a piece-rate labor market suggests a direct test of the efficiency of the mine-labor market would be to compare predicted factor shares from a Cobb-Douglas production function with actual shares. The results indicate miners, in union and nonunion counties alike, were paid a factor share below what was predicted and were exploited in a neoclassical sense. The results suggest the organization of the labor market into company towns created an inefficient labor market.

LAWRENCE W. BOYD, University of Hawaii at Manoa

\section{The Determinants of Bargaining Power in an International Cartel: Dow and the Deutsche Bromkonvention, 1908-1914}

In 1908, the Dow Chemical Company and the German Bromine Convention, sister cartel to the German potash combine, agreed to divide markets and set prices for bromine worldwide. This agreement ended a three-year-long price war that had undermined the profitability of the innovative, but young, Dow Company. Europe became the exclusive territory of the Germans, North America of the Americans, and the "Rest of the World" neutral, at agreed-upon prices. Despite Dow's superior technology, the Bromkonvention's use of German cartel laws to subsidize dumping and prevent entry forced Dow to accept an agreement in which it ceded market share in return for a cash indemnity. Dow hoped to retain substantial export markets in the "Rest of the World," but having agreed to refrain from price competition, found its low cost technology no longer provided a competitive advantage. Instead, German chemical firms, with a full product line and well-developed international distribution networks, captured virtually all neutral territory sales. Dow's position further weakened as it became increasingly concerned about American antitrust prosecution. To protect itself, in 1913 Dow made the Bromkonvention its exclusive distributor outside of North America. As a result Dow lost those few export markets it had retained.

MARGARET LEVENSTEIN, University of Michigan and National Bureau of Economic Research

\section{Domestic Integration and the Impact on Foreign Markets: The European Coal and Steel Community and the Entente de Bruxelles}

Much of the evaluation of the European Coal and Steel Community has been within the framework of broader European integration, especially those studies concerned with the political and security issues of European integration. This approach makes sense given the importance of iron, steel, and coal right after World War II and of the ECSC's importance as a pan-European organization. However, this orientation obscures the underlying economic impact of the ECSC and especially ignores the private-firm responses to the regulation of the ECSC. The ECSC's direct economic impact was 
probably small, yet it had profound effects on firm behavior. This paper explores the impact of the ECSC on trade with non-ECSC countries. I argue that because internally traded products like ingots were strategic complements to foreign trade in products like sheets and plates, the ECSC increased global trade of the ECSC countries. I also examine the operation of the Bruxelles Entente, an export cartel, and argue that it was supported by the ECSC, especially in the ability of firms to exploit cross-market retaliation; in effect, the ECSC extended multimarket contact, causing firms to forbear violating price and market-segmentation agreements.

Daniel. Barbezat, Amherst College

\section{Concentration and Firm Size in Western Economic Development: A Comparison of Official Census Statistics in the U.S., Britain, France, and Germany, 1905-1911}

Existing literature regarding Western economic development argues that at the turn of the century the United States and Germany benefited from large-scale enterprise, whereas the French and British economies were hindered by small-scale industry and the failure to adopt the form of the modern corporation as seen in the United States and Germany. Despite this interest in industrial structure, there have been almost no systematic and comparative investigations of European and American firm size for the period from 1880 to 1914 . This paper makes use of the official census data to test some existing conjectures in the literature and to generate accurate descriptions of the overall structural features of these nations' industries at the turn of the century. We use employment data to derive four measures of establishment size for most industry classifications as well as an overall total. We also examine asset size and capitalization data for the 100 largest firms in the four countries. We dismiss the generally accepted view by showing that French establishments were generally as large, and often larger, than those in the United States, whereas Germany was distinguished by its small scale of enterprise. Finally, we speculate on the importance of these results for rethinking our traditional analysis of industrial development in the early twentieth century.

JANICE RYE KINGHORN AND JoHN VINCENT NyE, Washington University

\section{Establishing a Monetary Union: The United States's Experience}

Because of experiences with bills of credit, the framers of the United States Constitution were aware of two problems that exist with a multiple-issuer fiat money system. The first is that in the absence of currency controls (legal restrictions that require the use of a particular money), one fiat money issuer has an incentive to collect seigniorage not only from those who use its money but also from those who use the money of other issuers. The second is that exchange rates can be variable and that such variability will have social costs in the absence of complete markets for sharing risk. In this paper we argue that these problems do not necessarily disappear in a multiple-issuer representative money system like that established by the Constitution. The United 
States's experience shows that multiple-issuer representative money systems may not produce monetary unions without government intervention. A monetary union did not emerge in the United States until Congress intervened with a series of reforms, starting with the National Currency Act of 1863 and ending with an amendment to this act in 1874.

ARThUR J. Rolnick, Federal Reserve Bank of Minneapolis, BRUCE D. SMITH, Federal Reserve Bank of Minneapolis and Cornell University, AND WARREN E. WEBER, Federal Reserve Bank of Minneapolis

\section{Redistribution, Coalitions, and the New Deal Relief Programs}

One common theme of New Deal history has been the supposed conflict between economic groups over redistribution of income. The New Deal relief programs instituted redistribution on a massive scale, involving billions of dollars and millions of families. Was the "battle for relief" primarily fought over class lines separating the rich from the poor and elites from the masses? The evidence presented in this paper suggests that rather than a struggle among redistributive coalitions, the major issues involved in the structure of the relief programs were political. Specifically, politicians at the federal, state, and local levels were interested in locating political control over the administration of the relief programs within their sphere of influence. Ultimately, all three levels of government had a say in running the programs. As a result, the return of administrative control over relief to the state and local governments in the Social Security Act of 1935 does not appear to have been a victory of local political elites anxious to guard their prerogatives. Instead, it was the result of a political compromise between the three levels of government.

John Wallis, University of Maryland, College Park

\section{Down and Out or Up and Out? The Occupational and Financial Mobility of Nonpersisters in the Antebellum United States}

Though the geographic, occupational, and financial mobility of average Americans were important aspects of nineteenth-century U.S. economic development, the extent and correlates of this economic mobility have remained open to debate in the absence of individual-level longitudinal data. This study uses a new sample of 3,000 individuals linked from the 1850 Public Use Micro Sample of the federal census population to the 1860 federal census manuscript schedules to explore these issues. The evidence suggests that common laborers who changed county of residence did no worse in occupational mobility and wealth accumulation, and perhaps did slightly better, than those who remained in the same place, despite Thernstrom's suggestion that movers represented a "floating proletariat" in this period. Nonlaborers who changed county did somewhat worse in occupational mobility and wealth accumulation than nonmovers.

JoSEPH P. FerRIE, Northwestern University 


\section{Family Labor Market Activity and the Effects of the Great Migration: African-American Nonmigrant Men and Women in the South, 1950-1960}

The "Great Migration" of African Americans has been much studied; less attention has been accorded to those who remained in the South. From 1950 to 1960, AfricanAmerican southern-male labor force participation declined sharply, whereas that of women rose. This paper examines the causes of these changes. It is found that mechanization in agriculture and out-migration acted to lower the labor force participation rate of males left in the South. For females, the added-worker effect in the context of the husband's unemployment led to increased participation, whereas the discouraged-worker effect led to decreased participation for the same sample of town-and-city married women. Employed women increasingly moved out of domestic service and into other occupations, albeit slowly. In contrast to town-and-city women, farm women's participation decisions were only weakly affected by their husband's labor force activity. All southern married women increased their participation with schooling. Those nonmigrants most adversely affected by mechanization in agriculture and migration were African-American males, implying that a shift of focus is warranted from migrants to nonmigrants.

Craig W. Heinicke, Baldwin-Wallace College

\section{Sugar, Strategy, Sovereignty: Toward a Political Economy of the Overthrow and Annexation of Hawaii}

We argue that a divergence between the economic and political power of Hawaii's white economic elite culminated in the 1893 overthrow of the Hawaiian monarchy and the islands' annexation to the United States in 1898. Over the nineteenth century, the United States, Britain, and France competed for influence on the Hawaiian monarch. Supporters of closer ties between the United States and Hawaii viewed annexation and a reciprocal trade treaty as alternative strategies. Trade reciprocity finally arrived in 1875 , and Hawaii sugar began to enter the U.S. market duty-free. The resulting boom in sugar production transformed Hawaii's labor economy by raising incomes and generating large labor flows from China and Japan. The United States failed to benefit economically from reciprocity, suggesting that U.S. officials considered political and strategic interests paramount. A division between the political and economic power of sugar and merchant interests in Hawaii emerged in the 1880 s as indigenous Hawaiians objected to foreign influence. Unfortunately for merchants and planters, the U.S. McKinley Tariff of 1890 placed sugar on the free list, plunging Hawaii into depression. Over the next two years Queen Liliuokalani feuded with the merchant-planter party and moved to promulgate a new constitution that would bolster the crown's powers. Under the eyes of American troops, a relatively small group of men spearheaded a successful revolution with the purpose of annexing Hawaii to the United States. However, annexation was delayed and might not have occurred at all, had not the Maine sunk in Havana Harbor in February 1898.

Christopher Grandy and Sumner J. La Croix, University of Hawaii at Manoa 


\section{The Regional Distribution of Patents in the United States: Invention and Uneven Regional Development}

Economic development occurs unevenly across regions and nations. Increasingreturns theories interpret this development as a cumulative process in which development in some regions leads to innovation that reinforces their advantages over other regions. This paper applies these theories to interpret the regional distribution of patenting in the United States from 1897 through 1925. A sample of 446 patentees is developed to show that inventors and their patents were unevenly distributed across regions. This unevenness is interpreted to be the outcome of (1) the location of manufacturing, especially of machinery; (2) networks of cities that coordinated the flow of goods and information within and between regions; and (3) urban, innovating firms within this network. The paper concludes by arguing that uneven regional invention can reinforce inequalities of economic development.

Ross Thомson, University of Vermont

\section{Planning the Bell System, 1888-1914: Building Long Distance Networks in Telephone Networks in Core and Peripheral Regions}

Between 1888 and 1914, AT\&T forged a long distance telephone network of continental proportions. By the end of the period, however, the Bell System contained pronounced gaps, notably in the Deep South and Great Plains. To explain the lagged diffusion of telephone service in the South, historians have emphasized the impact of sharecropping and myopic local entrepreneurs. Drawing on the insights and practices of contemporary telephone managers and engineers, I offer an alternative, but not opposing, explanation. Network expansion, their planning models implied, is a cumulative process, depending on and reinforcing urban-regional development. From this perspective, the "partially developed" long distance network in the South simply mirrored the region's fragmented urban system. Rural telephone agents in the territory blamed plantation agriculture for their dilemma, because it short-circuited the vital rural-urban interactions that would generate demands for telephone services. Although Bell operating companies and local capitalists jointly financed the construction of local networks, breaking out of this vicious cycle ultimately required large developmental investments, which exceeded their strategic vision and financial capacities. Consequently, network development in the South relied more heavily on external sources of finance and entrepreneurship, in particular direct intervention by AT\&T.

David F. Weiman, Queens College, CUNY

\section{Post-World War II Technological Change: Mechanization of the Cotton Harvest}

Although field hands manually harvested almost all of America's cotton in 1950, within two decades farmers gathered the crop exclusively with John Deere and International Harvester machines. Although a number of scholars have examined the 
causes and consequences of cotton mechanization, data limitations have confined the scope of those projects to the process of tractorization. A recently discovered data set indicates the number and type (picker or stripper) of mechanical cotton harvesters owned in each of Texas's 254 counties from 1948 to 1962. Of various economic, institutional and environmental factors, I estimate the determinants of mechanical cotton harvester adoption and the choice between the two alternative technologies, the mechanical stripper and picker. The rapid and widespread employment of cotton harvesting machines represents the last massive substitution of capital for labor in U.S. agriculture, as millions of southern farm workers left the fields forever.

WAYNe A. Grove, Syracuse University

\section{Was Hydroelectricity Regulated in Quebec in the 1930s? Assessing the Impact of the First Electricity Commissions}

The two central provinces of Canada followed very different roads in dealing with the electric power industry. Whereas Ontario nationalized its industry from the beginning, Quebec electric-power ownership remained in the hands of a few large private firms until 1962. 1962 was the last stage of a gradual progression whose beginnings can be traced back to the 1930s. As in the United States, the controversy around the electricity "trust" was a major political issue in Quebec in that decade. To calm political agitation, the government set up the first regulatory electricity commission in 1935 . Was the regulation effective or was it just "window-dressing"? We address this question in three ways. Qualitative evidence is provided by board reports, newspapers, and historical accounts. Financial returns are analyzed to test whether firms expected to be affected. The rate differential between Quebec and Ontario is examined to evaluate the actual impact. All three perspectives point at ineffectiveness. Political economy explains quite well the reasons for the ineffectiveness. Consumers were numerous but mostly unorganized, divided because of the large gap between domestic and industrial rates, and electorally underrepresented because of the Canadian political system. Producers were a small and tight group with large financial means and very close relationships with the Quebec government.

Ruth Dupré, Patrick Joly, and Michael Patry, Institut d'économie appliquée, Ecole des Hautes Etudes Commerciales de Montréal

\section{The Constructive and Destructive Uses of Power}

There are many examples of economic growth under autocracies from ancient times until today. Yet the most enduring economic advances occurred, in ancient as well as modern times, in nonautocratic and republican societies. This varied experience is partly due to the extent to which the governing interests in different societies had "encompassing" interests, which are favorable to economic advance, or "narrow" interests, which are not. Economic growth in relatively democratic regimes has occurred mainly because of their more secure contract and property rights, whereas the advantage of strong autocracies has been their imperviousness to special-interest lobbies. 


\section{The Economic History of Southeast Asia through Japanese Glasses, 1970-1990}

In the spirit that one's theory of economic history and development can best be tested by examining the diagnoses and predictions it has made in the past, this paper surveys pronouncements by Japan's social scientists made 10 to 20 years ago against the background of the economic history of Southeast Asia in the last 20 years. The survey found that the almost-neoclassical theory of economic history and development, endorsed by Teiichi Ito and myself among others-which emphasizes supply-side conditions, in particular the overwhelmingly important role of the quality of human resources-seems to have been vindicated in the main by the recent economic history of Southeast Asia. In contrast, the weaknesses of other types of theories are clearly revealed. Thus, structuralist theories and exploitation theories are found to be irrelevant. Similarly, sociocultural theories, such as theories of patrimonialism and ersatz capitalism-still popular among students of Southeast Asia-are shown to be wrong or outdated as of the end of the $1980 \mathrm{~s}$.

Yasukichi Yasuba, Osaka Gakuin University

\section{Lessons for the United States and the European Community for the Integration of High-and Low-Income Economies}

This paper draws on the experiences of the United States and the European Community to speculate on the effects of agreements to integrate high- and low-income economies. It focuses on how political and other institutional changes affect the pace and extent of income convergence. The evidence suggests that reducing barriers to the flow of goods or resources will promote convergence, even among integrating countries with disparate incomes. Convergence may be slow, however, even when impediments to integration are significantly lowered. We are struck by the extent to which politics shape the outcome of integration agreements, and how domestic and international policies are used to offset distributional constraints on economic growth and convergence. Thus, although integration seems to promote income convergence, even among high- and low-income participants, the nature and effects of integration agreements will depend on the institutional environment in which they operate.

Cletus C. Coughlin and David Wheelock, Federal Reserve Bank of St. Louis

\section{Why Chamberlain Failed and Bismarck Succeeded: The Political Economy of Tariffs in British and German Elections}

We analyze three crucial elections that determined the fate of free trade in Britain and Germany. These are the elections of 1906 in the United Kingdom and those of 1877 and 1878 in Germany. We examine the political economy of trade policy by analyzing the voting patterns of the electorates in their choice of commercial policy. The underlying hypotheses to be explored is that voting behavior was based on the economic interests 
of the constituents as determined by the international-trade performance of the sector in which they were employed. An econometric model reveals the degree to which the support for and opposition to free trade was based on occupational characteristics and explains well the outcomes in 1877 and 1906. In 1878 religious affiliation and turnout played a significant role in the result, although not in the ways assumed by historians. Our model shows that although franchise restrictions helped free trade in Britain, their absence had no impact on the results in Germany.

Douglas A. Irwin, University of Chicago, and Adam Klug, Ben-Gurion University

\section{Price and Quantum Indices of the United States- Cuba Trade, 1821-1898}

Price and quantum indices constructed for trade between the United States and Cuba from 1821 to 1898 display the following trends. The net barter terms of trade of Cuba with the United States (increasingly Cuba's largest trading partner) generally fell, suggesting that Cuba provides a good example of the Prebisch thesis. However, the income terms of trade run counter to the net barter terms of trade, rising through the 1840 s and 1850 s, through most of the 1860 s, and sharply again until 1874 . U.S. demand for Cuban sugar was price elastic. Increases in quantity offset the fall in Cuban export prices, so that the purchasing power of Cuban exports continued to grow. This was not, then, an example of "immiserating growth" after all. Even as the relative price of Cuban exports fell, the island's capacity to import still grew. The composition of U.S. exports to Cuba changed as the share of "food" products (flour, beef, fish, and rice) declined from the 1820 s through the 1850 s and 1860 s, reflecting a resurgent Castilian imperialism in the 1830 s and 1840 s. The share of "nonfood" products (wood, iron, coal) rose from the 1820 s through the 1850 s and 1860 s, indicating that inputs used to mechanize the sugar industry were welcome.

Linda K. Salvucci and Richard J. Salvucci, Trinity University

\section{The Cuban Agricultural Economy Before the Ten Years' War}

As one of Spain's last colonies, Cuba occupied a unique position within Latin America during the nineteenth century. Estimates of Cuban agricultural performance indicate a dynamism absent from the region's other economies in this period. In Cuba, real crop output more than kept up with the island's growth in population. Although per capita production of food crops declined, export production rose dramatically, as resources were redirected into the burgeoning sugar sector. These estimates also suggest that the average product of labor in agriculture was not much less than that of the United States in the same period. Institutional and technological change account for much of the island's exceptional experience in nineteenth-century Latin America. Despite its continuing formal ties to the mother country, Cuba experienced a number of important institutional changes early in the century. These changes moved Cuba toward a more fluid and open market economy than was found elsewhere in the region. Institutional changes also made Cuba more amenable to the adoption and diffusion of 
new technologies. Cuba became the first region after the United States to construct railroads, dramatically lowering overland freight costs, creating appreciable external benefits, and extending the feasible margin of cultivation. The net effect of these changes was to raise productivity above that found elsewhere in Latin America.

William Summerhill, University of California, Los Angeles

\section{Cane Fires and Crisis Management: Why Were Sugar Cane Supply Contracts Different in Cuba and Hawaii? 1899-1925}

In the postslavery sugar industry, studies have shown that transaction costs associated with sugar cane processing favored internalization of the cane transaction in a vertically integrated firm structure. Anomalously, many countries did not adopt a vertically integrated structure but rather obtained cane from long-term contractual arrangements with cane farmers. This paper compares two countries-Cuba, where cane was supplied by farmers, and Hawaii, where cane cultivation was internalized. I argue that, although high holdup costs inherent in modern sugar production techniques provided incentives for internalization, in Cuba relatively high costs of monitoring the performance of canefield managers offset the holdup costs that had provoked many other countries to adopt a vertically integrated structure. Evidence points to two reasons: (1) A relatively high capital intensity of cane cultivation in Hawaii likely reduced the marginal costs of monitoring the canefield manager because of economies of scope. (2) The high incidence of cane fires in Cuba was one of the principal sources of higher monitoring costs. The built-in incentives of the market were used to encourage better vigilance of the fields. In Hawaii, vigilance was not an important task of the canefield manager because fields were purposefully burned there as a means to reduce labor costs.

Alan Dye, University of Michigan

\section{Why Crowding Out Did Not Occur and Crowding In Did: A New Look at the History of the British National Debt, 1694-1994}

National debt, defined as the stock of financial obligations issued by the legitimate government of a sovereign nation, has its tricentennial in 1994. In 1694, the English Parliament sold perpetual bonds to the newly chartered Bank of England. Further issues of debt followed in response to the pressures of war finance. The evidence indicates that the periodic increases in the size of the British national debt did not "crowd out" private domestic investment, but decreases did "crowd in" capital formation. Apparently, the increased liquidity brought by marketable national debt benefited not only savers and investors in the economy but especially traders in the secondary markets for securities. 


\section{Government Debt and Private Capital Markets: England, 1727-1837}

By 1824, as a result of the protracted struggle with France for dominance in Europe, the British Government debt was almost 2.5 times GNP. When we examine rates of return on a variety of private assets in England from 1727 to 1837, we find no evidence that the mounting debt crowded out much private investment in the British economy. Nor is there evidence that the government debt was financed by large capital imports. The rise of government debt in the late eighteenth century must have created great increases in private saving. The mechanism by which this increase in saving occurred is unclear, and the rise is indeed quite puzzling.

Gregory ClaRK, University of California, Davis

\section{The Process of Modern Economic Growth and Changes in the Income Distribution: The Netherlands, 1800-1913}

In this paper we examine the development of income and inequality and its relationship to the process of "modern economic growth" in the Netherlands during the nineteenth century. Data on the development of real wages, the distribution of income by factor shares, sectoral and regional income differences, and the pay ratio between unskilled and skilled labor are presented. On the basis of these data, an upswing in the Kuznets curve could not be discerned in the nineteenth century. The distribution of income by factor shares remained fairly stable. As far as income by size is concerned, there is clear evidence for a downswing with decreasing sectoral, regional, and occupational differences and a diminishing of the overall skill premium. Increasing real wage levels and the overall catching-up of unskilled laborers' wages were especially important factors for the development of some industrial companies that were oriented to the domestic market. Our research does not mean that we should abandon the idea of an upswing in income inequality for the Netherlands in the nineteenth century altogether. On a disaggregate level, we found clear evidence for the existence of increasing inequality levels between high-income groups in the newly industrializing cities, which is in line with Kuznets's expectations.

Jan-Pieter Smits and AnNelies VermaAs, Universiteit Utrecht

\section{Tracing the Beginning of the Kuznets Curve: The Inequality of Income and Wealth in Western Europe During the Early Modern Period}

This paper attempts to answer the question whether there was a systematic relationship between economic development and (changes in) income distribution in Europe between 1500 and 1800 . On the basis of a number of detailed studies of the structure of income and wealth inequality in different regions of Europe (from Tuscany in 1427 to Overijssel in 1751) and a case study of the development of income inequality in Holland 
between 1561 and 1808 , the hypothesis is formulated that economic growth in the early modern period led to an increase in the inequality of the distribution of income. Moreover, it is shown that in this period the skill premium-the ratio between the salaries of employees and the wages of laborers in the building industry-increased in the two cities for which detailed information is available, Vienna and Amsterdam. Finally, three theoretical approaches are used to explain the relationship between economic growth and changes in income distribution in the early modern period.

JAN L. VAN ZANDEN, Universiteit Utrecht

\section{Income Growth and Inequality: Considering the New York Housing Censuses, 1855-1875}

This paper deals with the distribution of income, as measured by all dwelling values coupled with household characteristics reported in the New York state censuses of 1855 to 1875 . I believe the data from these censuses may yield our best nineteenth-century estimates of income inequality, that is, our best statement of a Lorenz curve below the median. Each distribution of dwelling values demonstrates a Gini coefficient (G) of between .5 and .6 , and an approximate lognormal shape, with the $G$ being a little less in 1875 than in 1855, and reveals substantially more inequality than does today's dwelling distribution (about .55 then and .45 now). This shows a long-run process of "filling in" rather than the "hollowing out" that is found since 1970. Mean dwelling values show substantial growth from 1855 to 1875 , and results suggest amending Henry George's 1879 title to Progress and Less Relative Inequality. The New York data for dwelling value per occupant or value per adult male occupant capture some most revealing aspects of distribution. Relative inequality $(G)$ in New York was as large in rural as in urban areas, as large in the $\mathbf{2 5}$ rural townships surrounding Buffalo as in Buffalo itself. A plane ride over Erie County in 1855 or 1875 would show mansions, frame houses, log cabins, and shanties; but Lorenz curves among adult males who were property owners were similar to those for nonproperty owners. The G for adult male "laborers" was over .5 , surely not a homogeneous mass of individuals below the median or mode.

LeE Soltow, Ohio University

\section{No Experiments, Monumental Disasters: Why It Took a Thousand Years to Develop a Specialized Fishing Industry in Iceland}

An equilibrium trap held the Icelanders in abject poverty until the late nineteenth century and prevented them from effectively exploiting their renowned fisheries, which attracted fishers from various European countries. The institutions of premodern Iceland gave priority to subarctic farming of low productivity and permitted ocean fishing only as a part-time activity. An independent fishing industry was held back by landed interests, who, fearing competition in the labor market, tied labor to the land. Yet, the evidence suggests that in an open economy, local entrepreneurs would have overcome these barriers. However, the equilibrium trap had a foreign component that was a binding constraint: the Danish colonial policy of isolation and monopoly trade, which reflected security considerations and an unwillingness to invest in a strong 
presence in Iceland. Severe economic conditions in eighteenth-century Iceland made the Danes revise their policy and gradually open the economy. The slow transition to a new economic system lasted a whole century, and the restrictive regulations in the labor market were abolished only when economic forces had rendered them irrelevant.

THRÁINN EggerTsSON, University of Iceland and University of Indiana

\section{Institutional Change in Income Assistance: Fiscal Federalism During the Lancashire Cotton Famine}

Institutional change in income assistance arose from the unanticipated and unprecedented depth and duration of the Lancashire cotton famine (1861-1865). The chronological progression of this institutional change revealed a move from decentralized to centralized funding of assistance. The organizational structure of these newly created private charities exemplified the benefits of fiscal federalism. A central organization, the Manchester Central Committee, collected international contributions and disseminated them to a single local relief committee in each town in Lancashire. Changes in the margin between the information benefits of decentralization and the ex post lossspreading benefits of centralization motivated this institutional change. Relative information costs decreased because of the concentration and duration of the distress, which decreased the opportunity cost of centralization. Lancashire, which specialized heavily in cotton textiles, was vulnerable to a large industry-specific shock; because authorities could not readily spread the income loss though diversified employment they redistributed through centralization of funding at the national level. Newly gathered data from the monthly reports of the Manchester Central Committee demonstrate that by early 1863 , central sources provided most of the funding of local charity.

L. Lynne Kiesling, College of William and Mary

\section{Institutions and the Environment in Draft Animal Choice: A Panel Study of the Italian Countryside, 1908-1931}

In premechanized agriculture, draft animals provided virtually all motive power. Different agrarian systems used different animals, and the conventional wisdom is that such differences can be explained as a result of varying physical conditions such as heat and rainfall. This paper takes issue with this view and argues that different animals were used largely to assuage principal-agent problems. The wide variety of local conditions and tenancy systems in use in Italian farming in the first half of this century offers an excellent case study to test alternative explanations of draft-animal choice. Using panel data analysis for two sets of demographic and livestock data, we show that institutional arrangements played a large role in the choice of different types of work stock, while also confirming the importance of certain local conditions.

Francesco L. Galassi, University of Leicester, and Kyle D. Kauffman, Wellesley College 


\section{Prices and Famine in Early Modern England: An Analysis of Tudor-Stuart Public Policy}

In 1857 the English Privy Council issued the Book of Orders, a centralized faminerelief program that called for restrictions of grain markets with measures that included the confiscation and redistribution of private inventories. Previous studies, including recent work by Robert Fogel, have noted the correspondence of this policy to a significant reduction in variation of English grain prices. Fogel argues that such a policy was necessitated by an exceedingly inelastic demand for private inventories by early modern stockholders. He estimates that in no period in the 300 years after 1500 was shortfall in grain larger than the amount held in storage. Famine was therefore avoidable given proper restriction of grain hoarding. In order to examine the theoretical justification for this policy, I present and test a contrasting competitive model of grain storage. Evidence suggests stock levels were responsive to prices, making the existence of large private stocks in famine periods unlikely. Regarding the empirical support of dearth orders, I find that similar price stabilization occurred in many English goods markets not affected by the orders. Stabilization also occurred in grain markets throughout Europe in the period. This suggests English market restriction was not the causal factor.

RaNDall NIELSEN, Washington University

\section{The Coevolution of Property-Rights Regimes for Land, Man, and Forests in Thailand, 1790-1990}

The commercialization of the Thai economy during the nineteenth and twentieth centuries was associated with the gradual creation of a cadastral-survey-based system of land titling, gradual dismantling of property rights in man, and the creation of a state-property rights regime in forests. Private property rights in crop lands served the export economy. The dismantling of human property rights was motivated in large part by an intraelite power struggle. The creation of state property rights in forest lands was, in part, the by-product of the extension of the central (Bangkok) government's authority into the northern teak forests. Widespread logging and extralegal logging followed by clearing for agricultural use led to extensive deforestation. Although natural resource rents for forest products were captured by government officials and logging interests, in general, agricultural producers who cleared forest lands obtained ownership rights. Standard analyses have focused on the effects of a particular system of property rights on efficiency and equity isolation. The paper considers the effects of the configuration of evolving systems of property rights in land, man, and trees. Counterfactual configurations are considered briefly. These include the creation of alternative private or communal rights in forests.

DAVID FEENEY, McMaster University

\section{Possession is Nine Points of the Law: Land Auctions, Squatting, and the Preemption Acts}

Early public-lands disposal policies underwent an evolution over time, from a system based exclusively on auction bidding to one that also included preemption as a key component. This evolution appears closely linked to difficulties experienced by the 
federal government in enforcing its property rights to the public lands, which resulted in large amounts of squatting activity. This study documents the early political influence of squatters and provides evidence that they contributed to the passage of the general preemption acts of the 1830's.

Mark T. Kanazawa, Carleton College

\section{Property Rights: Asked, Open, and Unasked Questions}

This paper surveys many of the questions addressed to date in the property rights literature, outlines a number of open questions, and identifies a class of questions that remain unaddressed in the literature. Scholars have posed a wide range of questions: they may broadly be categorized as those that examine the relationship between the structure of property rights and economic outcomes and those that examine the causes and consequences of change or failure to change. Despite active research, both questions remain open. The relationship between rights and outcomes when rights lie between the extremes of secure property rights and common property is not well understood, and the study of change has been severely hindered by the absence of a theory of the state that can explain the behavior of the executive, judicial, legislative, and administrative branches. The class of changes associated with radical alteration of the existing structures of rights such as changes in government through territorial acquisition remain unaddressed. The paper raises a number of empirical and theoretical questions regarding the institution established by the United States to handle the changes in property rights following the acquisition of California from Mexico.

KaREN Clay, University of Toronto

\section{Property Rights, Competition and Depletion in the Eighteenth-Century Canadian Fur Trade: The Role of the European Market}

We explore the impact of the European market on the pricing of beaver furs at Hudson's Bay Company trading posts. The Company recognized that high prices to the Indians would lead to overharvesting; but it faced a loss of market share to the French if it failed to raise prices at its posts in years when European fur prices were high. Modeling the decision as an optimal-control problem, we find that where the Company faced no competition, its profit-maximizing strategy in the face of rising prices in England was to maintain prices at its posts to prevent depletion. But where the French were active, the best the Company could do was increase prices despite the adverse effect on animal stocks. From 1713 to 1763, the pattern of fur prices in England and at the different posts conforms closely to these strategies. Although, potentially, Natives could have controlled harvesting, tribal conflict, migration, and other factors prevented them from gaining secure property rights to the animals.

Frank D. Lewis, Queen's University, AND ANN M. CARLos, University of Colorado and Queen's University 